\title{
PENGARUH TERAPI BEKAM PADA TITIK REFLEKSOLOGI DENGAN AROMATERAPI LAVENDER OIL TERHADAP PENURUNAN TEKANAN DARAH PADA PENDERITA HIPERTENSI
}

\author{
Rizqa Wahdini ${ }^{*}$, Syarif Safarudin ${ }^{2}$, Diah Oktaviani ${ }^{3}$ \\ 1.2.3 STIKes Yarsi Pontianak \\ Korespoonden: \\ Rizqa Wahdini : Program Studi Pendidikan Profesi Ners, STIKes Yarsi Pontianak \\ Jln Panglima A'im, No.1 Kota Pontianak, Kalimantan Barat - 78232, \\ E-mail: rizqawahdini@gmail.com
}

\begin{abstract}
ABSTRAK
Latar Belakang: Hipertensi merupakan gangguan asimptomatik pada tekaan darah yang sering terjadi ditandai dengan peningkatan tekanan darah secara persisten. Penyebab hipertensi belum diketahui dengan pasti penyebabnya. Salah satu terapi komplementer yang dapat digunakan untuk menjaga keseimbangan tekanan darah yaitu terapi bekam yang berfungsi meningkatkan permeabilitas pembuluh darah, dibantu dengan aromaterapi lavender yang memiliki efek relaksasi sehingga mampu memperbaiki metabolism dan memperlancar pembuluh darah. Tujuan Penelitian: Untuk mengetahui pengaruh terapi bekam pada titik refleksologi dengan menggunakan minyak aromaterapi lavender terhadap penurunan tekanan darah pada penderita hipertensi. Jenis penelitian : Metode penelitian ini menggunakan metode kuantitatif yang menggunakan rancangan penelitian quasi experimen dengan pre post test without control. Teknik sampling yang digunakan dalam penelitian ini adalah simple random sampling sehingga diperoleh sampel sebanyak 16 orang. Hasil penelitian : Penelitian ini menunjukkan hasil signifikan yaitu terjadi penurunan tekanan darah pada penderita hipertensi setelah dilakukan intervensi yaitu high hipertensi sebanyak 3 responden dengan persentase sebesar $18,75 \%$, hipertensi grade I (ringan) sebesar 9 responden dengan persentase $56,25 \%$, dan hipertensi grade II (sedang) sebanyak 4 responden dengan persentase sebesar $25 \%$. Hasil uji wilcoxon didapat nilai $\mathrm{P}<0,05 \quad(\mathrm{P}=0,000)$. Kesimpulan : Adanya pengaruh terapi bekam pada titik refleksologi dengan aromaterapi lavender oil terhadap penurunan tekanan darah pada penderita hipertensi.
\end{abstract}

Kata Kunci : Hipertensi, Terapi bekam, lavender oil

\begin{abstract}
Background: Asimpomatik hypertension is a disorder of hte blood pressure peraisten. Because of hypertension in notknown with certainty. One of the complementary therapies that can be used to maintain blood pressure is cupping therapi that works to increase permiabelitas blood vessels, aided, with aromatherapy lavender has a relaxing effect so as to improve metabolism and accelerate the anterior hypothalamus which is the activation center vervous system. Type of research: To determine the effect of cupping therapy on reflexology points with aromatherapy lavender oil to the reduction of blood pressure in patients with hypertension. Research results : This research used quantitative, while the method is pre experimental with pre post test without control design. The sampling technique is simple random sampling there fore the selective sample are 16 peoples. The study shows a significant result which decrease blood pressure in patients with blood pressure after the intervention with 3 rrespondents (18,75\%), hypertension grade I (light) with 9 respondents $(56,25 \%)$, and hypertension grade II (middle) with 4 respondents (25\%). The result of the test is wilcoxon with value $P<0,05(P=0,000)$. There is effect of reflexology point with aromatherapy lavender oil to the reduction of blood pressure in patient with hypertension.
\end{abstract}

Keywords: Hypertension, cupping therapy, Lavender oil. 


\section{PENDAHULUAN}

Tubuh manusia terdiri atas sekitar $60 \%$ air yang terbesar di dalam sel maupun di luar sel. Untuk mempertahankan kesehatan dibutuhkan keseimbangan cairan, elektrolit, dan asam-basa didalam tubuh. Keseimbangan ini dipertahankan oleh asupan, distribusi, dan haluaran air dan elektrolit, serta pengaturan komponenkomponen tersebut oleh sistem renal dan paru. Orang dewasa yang sehat, aktif bergerak dan memiliki orientasi yang baik biasanya dapat mempertahankan keseimbangan cairan, elektrolit, dan asam basa yang normal karena mekanisme adaptif tubuhnya. Namun bayi, orang dewasa yang menderita penyakit berat akan sulit sulit mempertahankan keseimbangan cairan, elektrolit dan

asam-basa sehingga diperlukan terapi cairan (Potter \& Perry, 2006).

Terapi cairan atau terapi intravena (IV) adalah salah satu cara atau bagian dari pengobatan untuk memasukkan obat atau vitamin ke dalam tubuh pasien. Terapi intravena diberikan di semua pelayanan kesehatan, termasuk rumah sakit, klinik dokter dan perawatan dirumah pasien. Terapi intravena ini dapat diberikan pada neonatus hingga pasien lanjut usia (Phillips \& Gorski, 2014). Tujuan dari pemberian cairan intravena ini adalah untuk mengoreksi atau mencegah gangguan cairan dan elektrolit. Apabila pemberian cairan intravena dibutuhkan diprogramkan oleh dokter, perawat harus mengidentifikasi larutan yang benar, peralatan dan prosedur yang dibutuhkan untuk memulai, mengatur, dan mempertahankan sistem. Namun, ada risiko dan komplikasi dari pemasangan terapi intravena yang dapat mengancam kehidupan. Komplikasi yang dapat terjadi pada saat pemasangan terapi intravena adalah infiltrasi, beban cairan berlebih, perdarahan, serta flebitis (Potter \& Perry, 2006).

Flebitis merupakan salah satu infeksi nosokomial akibat dari luka pemasangan intravena, yang terjadi pada pasien ketika berada dirumah sakit atau ketika berada di fasilitas kesehatan lainnya. Dari sekian banyak jenis infeksi nosokomial, flebitis menempati peringkat pertama dibanding dengan infeksi lainnya (Nugraheni, 2012). Flebitis adalah peradangan yang terjadi pada pembuluh darah vena yang disebabkan oleh kateter atau iritasi kimiawi, zat aditif dan obatobatan yang diberikan secara intravena. Tanda umum flebitis yang biasanya timbul berupa eritema, nyeri, edema, dan peningkatan temperatur kulit pada area insersi atau di sepanjang jalur vena. Flebitis berpotensial membahayakan karena bekuan darah (tromboflebitis) yang terjadi dan pada beberapa kasus dapat menyebabkan pembentukan emboli (Potter \& Perry, 2006).

Berdasarkan data World Health Organization (WHO) infeksi nosokomial terjadi di seluruh dunia dengan kejadian terbanyak di negara miskin dan negara yang sedang berkembang karena penyakit-penyakit infeksi masih menjadi penyebab utamanya. Suatu penelitian yang dilakukan oleh $W H O$ tahun 2006 menunjukkan bahwa sekitar $8,7 \%$ dari 55 rumah sakit dari 14 negara di Eropa, Timur tengah, dan Asia Tenggara dan Pasifik terdapat infeksi nosokomial, khususnya di Asia Tenggara. Sedangkan di Prancis, prevalensi kejadian infeksi nosokomial sebesar $6,87 \%$ pada tahun 2001 dan meningkat menjadi 7,5\% pada tahun 2006 (Nasution,2012).

Angka kejadian flebitis yang direkomendasikan oleh Infusion Nurses Society (INS) adalah $5 \%$ atau kurang. Berdasarkan penelitian Ollivera,et al (2012) dari 1.244 yang terpasang infus, sekitar 317 orang $(11,09 \%)$ mengalami flebitis di ruang Perawatan Rumah Sakit Pusat Portugal. Jumlah kejadian flebitis menurut distribusi penyakit sirkulasi pasien rawat inap Indonesia Tahun 2009 
sebanyak 17,11\% (Ningsih,2012). Berdasarkan studi pendahuluan yang dilakukan di Rumah Sakit Universitas Tanjungpura Pontianak diperoleh data jumlah pemasangan infus sebanyak 226 orang, terdapat angka kejadian flebitis sebesar 12 orang $(5,3 \%)$ pada bulan April 2017. Di rumah sakit Universitas Tanjungpura Pontianak pada bulan Desember 2016 baru dibentuk program Pengendalian dan Pencegahan Infeksi (PPI) yang mengontrol terjadinya infeksi, salah satunya adalah infeksi nosokomial flebitis. Untuk pencegahan flebitis pada pemasangan infus program PPI membuat SOP pemasangan infus dengan menggunakan dressing transparan, tetapi angka kejadian flebitis masih diatas standar INS.

Tingginya angka prevalensi flebitis dipengaruhi oleh berbagai faktor-faktor resiko yang akan menjadi masalah kesehatan pada pasien jika tidak terkendali. Faktor-faktor resiko tersebut yaitu bahan kateter, ukuran kateter, lokasi insersi, jenis cairan,usia, jenis kelamin, serta penyakit penyerta (diabetes, penyakit menular, kanker, imunodefisiensi, serta vena perifer berkualitas buruk) (Phllips \& Gorski,2014). Potter \& Perry (2005) dalam Soraya (2014) menyatakan faktor resiko yang dapat menyebabkan flebitis adalah jenis cairan, usia, perawatan kateter infus, balutan, rotasi pemasangan, lama dirawat dan aktivitas dari pasien.

Seiring dengan penambahan usia maka akan terjadi berbagai perubahan fungsi tubuh baik secara fisik, biologis, psikologi dan sosial. Salah satu perubahan fisik tersebut adalah penurunan sistem imun tubuh. Tidak hanya fungsi imunitas yang turun, tetapi perubahan vena juga sering terjadi dengan bertambahnya usia. Flebitis dapat dipengaruhi karena faktor usia, hal ini dibuktikan oleh Rizky (2016), dalam penelitiannya mengungkapkan bahwa flebitis dapat terjadi pada remaja hingga lansia.

Upaya pencegahan dapat dilakukan pada flebitis adalah dengan mengganti dan memindahkan lokasi penusukan pada tempat yang lain apabila lebih dari satu minggu, cuci tangan yang baik dan benar, pertahankan teknik aseptik pada semua prosedur terapi intravena, gunakan sarung tangan bersih selama insersi, dan desinfektan kulit dengan antiseptik serta pemilihan jenis penutup tempat penusukan (dressing) yang tepat (Potter \& Perry,2006).

Dressing (balutan) merupakan suatu material yang digunakan untuk menutup luka. Balutan yang biasa digunakan yaitu balutan transparan dan balutan kassa. Balutan transparan disebut juga transparent semipermeable dressing (TSD) atau transparent membrane dressing (TMD) yang memungkinkan inspeksi visual pada sisi intravena, tidak mudah kotor atau lembab, dan tidak perlu diganti dengan sering dibandingkan balutan kassa. Balutan transparan merupakan standar untuk perawatan luka tusuk, dipercaya sebagai balutan ideal yang dapat mengurangi resiko terjadinya flebitis. Hal ini dikarenakan balutan transparan memenuhi kriteria balutan, yaitu untuk mencegah masuknya mikroorganisme pada luka tusukan, juga dapat memfiksasi kateter dengan kuat dan memungkinkan proses monitor untuk antisipasi terjadinya infeksi. Namun, pada pemasangan balutan transparan ini tidak menggunakan antibiotik topikal. Alternatif lain yang biasanya digunakan untuk menutup daerah insersi yang telah diolesi antibiotik adalah menggunakan balutan kassa (Soraya,2014).

Pemasangan balutan kassa pada sisi intravena digunakan untuk mengurangi masuknya bakteri pada sisi insersi. Balutan kassa untuk menutupi area insersi merupakan faktor yang mempengaruhi terjadinya infeksi flebitis. Hal ini, dipengaruhi karena faktor kelembaban. Kondisi lingkungan yang lembab akan menyebabkan mikroba akan lebih cepat berkembang, sehingga tempat insersi harus dijaga agar tetap kering. Untuk mencegah berkembangnya mikroba atau bakteri didaerah sekitar tempat insersi maka diperlukan zat 
antibiotik (Soraya,2014). Tetapi pada dasarnya, salep antibiotik merupakan zat kimia yang dapat menimbulkan efek resistensi apabila penggunaan dalam waktu yang lama, dan dosis yang tidak tepat. Oleh karena itu, bahan-bahan alami akan lebih baik digunakan untuk tubuh. Bahan-bahan alami yang memiliki manfaat yang menyerupai antibiotik diantaranya adalah, bawang putih, meniran, temulawak, kunyit, jahe, babandotan, sambiloto, beluntas, mimba, lidah buaya, daun sendok, kayu manis, serta madu (Utami,2012).

Madu memiliki sifat antiinflamasi, antibakterial, antioksida, dapat mempercepat penyembuhan luka serta sifat menarik air (higroskopis) pada madu membantu dalam penyerapan air sehingga dapat mengkondisikan lingkungan yang lembab menjadi kering (Utami,2012). Madu telah digunakan sejak dahulu kala untuk perawatan luka meskipun kini mulai digantikan dengan modalitas perawatan luka modern, madu memiliki keunggulan yakni salah satunya mampu melawan infeksi kuman yang resisten terhadap antibiotik. Apalagi hingga kini belum terbukti adanya resistensi kuman terhadap penggunaan madu jangka panjang. Penggunaan madu untuk perawatan luka sebaiknya juga turut memperhatikan faktor dilusi oleh eksudat (Gunawan,2017).

Madu bekerja sebagai antibiotik alami yang mampu mengalahkan bakteri. Madu bersifat sangat asam sehingga tidak cocok untuk pertumbuhan dan perkembangbiakan bakteri. Madu yang digunakan harus memiliki $\mathrm{pH}$ di bawah 4,0, karena bakteri patogen hanya bisa hidup pada $\mathrm{pH}$ antara 4,0-4,5. Madu juga menghasilkan senyawa hydrogen peroksida yang bertindak sebagai antiseptik. Hydrogen peroksida pada madu dapat menghambat sekitar 60 jenis bakteri aerob maupun anaerob termasuk bakteri gram positif dan bakteri gram negatif (Siswati \& Nasution, 2016). Arif (2013), menyatakan bahwa pada madu terdapat flavonoid yang dapat menghambat mediator-mediator radang yaitu mengurangi efek sitokin (Interleukin-1 dan Tumor Necrosis Factor (TNF)) yang dihasilkan oleh makrofag dan sitokin reseptor yang secara umum akibatnya tampak pada penekanan rasa nyeri, demam dan kerusakan jaringan.

Penggunaan antibiotik untuk mencegah flebitis sangat diperlukan. Tetapi penggunaan antibiotik kimia di beberapa rumah sakit, masih ditemukan belum efektif mencegah terjadinya flebitis pada pasien saat pemasangan terapi intravena. Berdasarkan hasil studi pendahuluan yang dilakukan di Rumah Sakit Universitas Tanjungpura Pontianak dan hasil wawancara terhadap petugas yang mengontrol mengenai program Pengendalian dan Pencegahan Infeksi serta observasi terhadap tanda dan gejala infeksi flebitis yang dilakukan pada tanggal 24 Oktober 2017 Di Instalasi Gawat Darurat di dapatkan hasil kejadian flebitis yang masih tinggi, sehingga peneliti tertarik untuk melakukan penelitian mengenai "Pengaruh Pemberian Madu Sebagai Antibiotik Saat Pemasangan Terapi Intravena Terhadap Pencegahan Flebitis di Instalasi Gawat Darurat Rumah Sakit Universitas Tanjungpura Pontianak.

\section{METODE}

Penelitian ini merupakan jenis penelitian kuantitatif. Desain penelitian yang digunakan adalah quasy experiment. Penelitian ini dimulai pada bulan Oktober yang di mulai dengan pembuatan proposal, setelah proposal di setujui di lanjutkan dengan penelitian pada tanggal 23 November 2017 sampai dengan 2 Desember 2017 di instalasi gawat darurat (IGD) Rumah Sakit Tanjungpura Pontianak.

Sampel yang digunakan dalam penelitian ini adalah Non Probability Sampling. Pengambilan sampel dilakukan dengan teknik Purposive 
sampling. Sampel yang diambil dalam penelitian ini didasarkan pada kriteria inklusi dan eksklusi yang dibuat peneliti sehingga seluruh sample berjumlah 36 sampel.

Analisa bivariat ini dapat berfungsi dalam mencari hubungan antar variabel yaitu variabel bebas pemberian madu dengan variabel terikat angka kejadian flebitis. Penelitian ini menggunakan uji statistik MannWhitney dengan batas kemaknaan kurang dari atau sama dengan 0,05 ( $p \leq$ $0,05)$. Penggunaan uji ini dikarenakan data pada kelompok kontrol dan kelompok intervensi berdistribusi tidak normal, sehingga tidak memenuhi syarat penggunaan uji $\mathrm{T}$ tidak berpasangan dan dianjurkan menggunakan uji alternatif. Hasi uji Mann-Whitney didapatkan nilai $p$-value $0,021(\mathrm{p}<0,05)$ sehingga $\mathrm{H}_{0}$ ditolak dan $\mathrm{H}_{\mathrm{a}}$ diterima.

Penelitian ini telah lolos kaji etik dengan nomor : 714/Ners/STIKes.YSI/XI/2017.

\section{HASIL}

1. Analisa Univariat

Analisa univariat dalam penelitian ini menjelaskan tentang karakteristik dari responden berdasarkan usia, jenis kelamin, jenis cairan, ukuran IV kateter, dan letak pemasangan.

1. Distribusi Karakteristik Responden Berdasarkan Usia, Jenis Kelamin, Jenis Cairan, Ukuran IV Kateter, dan Letak Pemasangan.
Tabel 3.1

Karakteristik Responden Berdasarkan Usia, Jenis

\begin{tabular}{|c|c|c|}
\hline \multirow{2}{*}{$\begin{array}{l}\text { Karakteristik } \\
\text { Responden }\end{array}$} & \multicolumn{2}{|c|}{ Responden } \\
\hline & $\bar{F}$ & $\%$ \\
\hline \multicolumn{3}{|l|}{ Usia } \\
\hline $12-16$ tahun & 5 & 13,9 \\
\hline $17-25$ tahun & 5 & 13,9 \\
\hline $26-35$ tahun & 6 & 16,7 \\
\hline $36-45$ tahun & 6 & 16,7 \\
\hline $46-55$ tahun & 6 & 16,7 \\
\hline $56-65$ tahun & 7 & 19,4 \\
\hline $65 \mathrm{ke}$ atas & 1 & 2,8 \\
\hline \multicolumn{3}{|l|}{ Jenis kelamin } \\
\hline Laki-laki & 15 & 41,7 \\
\hline Perempuan & 21 & 58,3 \\
\hline \multicolumn{3}{|l|}{ Jenis Cairan } \\
\hline Ringer Laktat & 35 & 97,2 \\
\hline Asering & 1 & 2,8 \\
\hline \multicolumn{3}{|c|}{$\begin{array}{ll}\text { Ukuran } & \text { IV }\end{array}$} \\
\hline Kateter & 8 & 22,2 \\
\hline 18 & 27 & 75,0 \\
\hline 20 & 1 & 2,8 \\
\hline 22 & & \\
\hline \multicolumn{3}{|l|}{ Letak } \\
\hline Pemasangan & 28 & 77,8 \\
\hline $\begin{array}{l}\text { Permukaan } \\
\text { dorsal tangan } \\
\text { Vena basalis }\end{array}$ & 8 & 22,2 \\
\hline Total & 36 & 100 \\
\hline
\end{tabular}

Sumber data : Data Primer (2017)

Berdasarakan tabel, didapatkan hasil penelitian menunjukan bahwa kategori responden berdasarkan usia terbanyak dalam penelitian yaitu pada kelompok usia 56-65 tahun dengan jumlah 7 responden $(19,4 \%)$. Pada karakteristik kategori responden berdasarkan jenis kelamin terbanyak yaitu perempuan dengan total 21 responden $(58,3 \%)$, sedangkan laki-laki lebih sedikit dengan total 15 responden $(41,7 \%)$. Pada kategori karakteristik responden berdasarkan jenis cairan, didapatkan penggunaan cairan ringer laktat lebih banyak dengan jumlah total 35 responden yang menggunakan cairan ringer laktat (97,2\%), sedangkan 1 responden $(2,8 \%)$ menggunakan cairan asering. Sedangkan pada karakteristik responden berdasarkan ukuran IV kateter, menunjukkan 
responden lebih banyak terpasang terapi intravena (infus) menggunakan ukuran IV kateter nomor 20 dengan total 27 responden (75 \%), sedangkan penggunaan IV kateter ukuran 22 lebih sedikit digunakan dari jenis ukuran lainnya dengan total 1 responden $(2,8$ $\%$ ). Pada kategori karakteristik responden berdasarkan letak pemasangan terapi intravena, didapatkan hasil letak pemasangan terbanyak yaitu pada daerah permukaan dorsal tangan dengan jumlah 28 responden $(77,8 \%)$, sedangkan 8 responden $(22,2 \%)$ pada vena basalis.

1. Analisa Bivariat

Tabel 3.2

Analisis Pengaruh Pemberian Madu Sebagai

Antibiotik Saat Pemasangan Terapi Intravena

Terhadap Pencegahan Flebitis di Instalasi Gawat Darurat Rumah Sakit Universitas Tanjungpura Pontianak $(\mathrm{N}=36)$

Kelompok $\quad \mathrm{N}$ Mean Mean $S D \quad Z \quad Z$ Rank Value

$\begin{array}{llllll}\text { Skor } & \text { Kontrol } & 18 & 0,94 & 22,17 & 0,873\end{array}$

Flebitis Intervensi $18 \quad 0,33 \quad 14,83 \quad 0,45$ $-2,311 \quad 0,021$

Sumber data: Data Primer (2017), telah diolah.

Dari tabel dapat dilihat bahwa analisis bivariat diperoleh nilai $p$ sebesar 0,021 ( $p<$ $0,05)$ artinya terdapat pengaruh pemberian madu sebagai antibiotik saat pemasangan terapi intravena terhadap pencegahan flebitis di Instalasi Gawat Darurat Rumah Sakit Universitas Tanjungpura Pontianak.

\section{PEMBAHASAN}

Pada poin ini peneliti akan membahas hasil penelitian tentang "Pengaruh Pemberian Madu Sebagai Antibiotik Saat Pemasangan Terapi Intravena Terhadap Pencegahan Flebitis di Instalasi Gawat Darurat Rumah Sakit Universitas Tanjungpura Pontianak" yang telah diuraikan sebelumnya. Pembahasan ini akan menjelaskan dan membandingkan hasil penelitian berupa karakteristik responden berdasarkan usia, jenis kelamin, jenis cairan, ukuran IV kateter, letak pemasangan dan pengaruh pemberian madu sebagai antibiotik saat pemasangan terapi intravena terhadap pencegahan flebitis dengan teori-teori yang telah ada serta hasil penelitian terhadap implikasi keperawatan dan keterbatasan dalam hasil penelitian yang telah dilakukan.

1. Karakteristik Responden

a. Usia

Berdasarkan hasil penelitian yang dilakukan di Rumah Sakit Universitas Tanjungpura, didapatkan responden terbanyak yang terpasangan infus yaitu pada rentang usia 56-65 tahun, dengan jumlah 7 responden $(19,4 \%)$. Menurut penelitian yang dilakukan Risky (2016) mengenai Analisa Faktor Yang Berhubungan dengan Kejadian Phlebitis pada Pasien yang Terpasang Kateter Intravena di Ruang Bedah Rumah Sakit Ar. Bunda Prabumulih, menyatakan bahwa terdapat hubungan antara kejadian flebitis dengan peningkatan usia dikarenakan daya tubuh lansia menjadi kurang efektif terhadap pertahanan infeksi dalam tubuh terutama pada sel T-limfosit sebagai hasil penuaan. Seiring dengan bertambahnya usia vena menjadi rapuh, tidak elastis, dan mudah hilang atau kolaps dikarenakan mengalami perubahan dalam struktur dan fungsi kulit seperti turgor kulit yang menurun dan epitel menipis, akibatnya kulit lebih mudah mengalami abrasi atau luka. Kejadian flebitis ditandai dengan adanya trombus yang terdapat di dinding vena. Adanya trombus meningkat di usia lebih dari 40 tahun, sehingga usia dianggap faktor resiko terjadinya trombus.

b. Jenis kelamin

Berdasarkan hasil penelitian yang dilakukan oleh peneliti di Rumah Sakit Universitas Tanjungpura didapatkan jenis kelamin responden terbanyak adalah perempuan dengan total 21 
responden terpasang terapi intravena (58,3 \%). Menurut penelitian Fitriyanti (2015), menyatakan bahwa perempuan lebih banyak mengalami flebitis dibandingkan dengan laki-laki. Hal ini dipengaruhi oleh kekuatan otot, kelenturan dan kekenyalan kulit serta jaringan adiposa subkutis yang berkurang. Wanita yang menggunakan kontrasepsi kombinasi (mengandung estrogen dan progesteron) mudah mengalami flebitis.

Hal ini didukung oleh penelitian yang dilakukan Soraya (2014), yang berpendapat bahwa perempuan secara biologis lebih lemah daripada laki-laki. Perempuan lebih beresiko terkena infeksi dan hal tersebut dikaitkan dengan hormon estrogen dan progesteron. Berdasarkan penelitian yang dimuat dalam Europen Journal Of Public Health mengungkapkan bahwa kesehatan perempuan lebih rendah menunjukkan beban lebih tinggi akibat penyakit yang mereka derita. Hal ini berarti bahwa perempuan lebih beresiko terjadi infeksi dibandingkan lakilaki (Soraya, 2014).

c. Jenis Cairan

Berdasarkan hasil penelitian yang dilakukan di Rumah Sakit Universitas Tanjungpura didapatkan jenis cairan yang banyak digunakan pada terapi cairan yaitu menggunakan cairan Ringar Laktat dengan total 35 responden (97,2 \%). Pemberian cairan intravena disesuaikan dengan kondisi kehilangan cairan pada pasien, seberapa besar cairan tubuh yang hilang. Pemberian cairan intravena merupakan salah satu tindakan invasive yang dilakukan tenaga kesehatan. Pada penelitian yang dilakukan oleh Rizky (2016) menyatakan bahwa cairan berhubungan dengan kejadian flebitis. Hal ini dikarenakan tingkat osmolaritas yang berbeda-beda pada setiap jenis cairan. Osmolaritas merupakan konsentrasi sebuah larutan atau jumlah partikel yang larut dalam sebuah larutan.

Menurut Fitriyanti (2015) dalam penelitiannya, menyatakan osmolaritas yang ekstrim selalu diikuti resiko kejadian flebitis yang tinggi. Semakin tinggi osmolaritas maka semakin mudah terjadi kerusakan pada dinding vena perifer, sehingga mudah untuk menarik cairan dan elektrolit dari jaringan dan sel ke pembuluh darah. Kecepatan pemberian larutan intravena juga dapat menyebabkan terjadinya flebitis. Pada pemberian dengan kecepatan rendah dapat mengurangi iritasi pada dinding pembuluh darah.

d. Ukuran IV Kateter

Berdasarkan penelitian yang dilakukan di Rumah Sakit Universitas Tanjungpura, ukuran IV kateter yang paling banyak digunakan pada saat pemasangan terapi intravena pada responden yaitu IV kateter nomor 20, dengan total 27 responden (75 $\%$ ), sedangkan penggunaan IV kateter ukuran 18 lebih sedikit digunakan dengan total 8 responden $(22,2 \%)$, dan 1 responden yang menggunakan ukuran $22(2,8 \%)$. Berdasarkan hasil penelitian yang dilakukan Nuhasanah (2016), menyimpulkan bahwa ukuran kateter berhubungan dengan kejadian flebitis. Pemilihan ukuran kateter, sebaiknya dipilih sesuai dengan anatomi vena pasien. Pada umumnya, pemilihan kanula dengan ukuran yang kecil seharusnya menjadi pilihan utama pada terapi pemasangan intravena untuk mencegah kerusakan pada vena 
intima dan memastikan asupan darah mengalir disekitar kanula dengan adekuat untuk menurunkan resiko kejadian flebitis. Apabila ukuran kateter tidak sesuai dengan ukuran vena maka akan beresiko untuk terjadinya flebitis.

Dalam penelitian yang dilakukan oleh Oktyaningrum (2016) juga mengungkapkan bahwa flebitis mekanik terjadi cedera pada tunika intima vena, flebitis mekanik berkenaan dengan pemilihan vena dan penempatan kanula atau kateter, ukuran kateter yang terlalu besar dibandingkan dengan ukuran vena, fiksasi kanula yang tidak adekuat, ambulasi yang berlebihan terhadap sistem dan pergerakan ekstremitas yang tidak terkontrol.

e. Letak Pemasangan

Berdasarkan penelitian yang dilakukan di Rumah Sakit Universitas Tanjungpura, letak penusukan insersi kanula banyak dilakukan di permukaan dorsal tangan dengan jumlah 28 responden $(77,8 \%)$ dan 8 responden $(22,8 \%)$ menggunakan vena basalis. Menurut penelitian yang dilakukan Lindayanti (2013) mengenai Hubungan Antara Tehnik Insersi dan Lokasi Pemasangan Kateter Intravena dengan Kejadian Flebitis Di RSUD Ambarawa, menyatakan bahwa flebitis dapat terjadi karena berbagai faktor yaitu pemilihan vena yang terlalu dekat dengan pergelangan tangan yang memudahkan untuk terjadinya aliran balik darah sehingga terjadi flebitis atau mudahnya kateter IV untuk bergerak dan terlepas. Hal ini dikarenakan posisi ekstremitas yang berubah, khususnya pada pergelangan tangan atau siku dapat mengurangi kecepatan aliran infus dan mempengaruhi aliran dalam darah. Penggunaan vena sefalika (lokasi jauh dari pergelangan tangan) lebih baik untuk digunakan. Letak vena mempunyai hubungan yang signifikan dengan kejadian flebitis disebabkan vena metacarpal (vena distal) letaknya lebih dekat dengan persendian dan mudah untuk digerakkan sehingga terjadi gesekan dinding vena oleh kateter intravena, hal ini sering terjadi pada pemasangan vena ekstremitas atas yang sering terpasang terapi intravena dekat persendian.

2. Pengaruh Pemberian Madu Sebagai Antibiotik Saat Pemasangan Terapi Intravena Terhadap Pencegahan Flebitis di Rumah Sakit Universitas Tanjungpura

Berdasarkan hasil penelitian bahwa terdapat pengaruh pemberian madu sebagai antibiotik saat pemasangan terapi intravena terhadap pencegahan flebitis dengan nilai $p$ sebesar $0,021(p<0,05)$. Hal ini membuktikan bahwa pemberian madu sebagai antibiotik pada saat pemasangan intravena berpengaruh terhadap pencegahan flebitis. Menurut Siswati \& Nasution (2016) dalam penelitiannya mengatakan bahwa madu memiliki karakteristik sebagai antiinflamasi, antibakterial yang dapat menghambat pertumbuhan bakteri. Madu bekerja sebagai antibiotik alami yang mampu mengalahkan bakteri. Madu bersifat sangat asam sehingga tidak cocok untuk pertumbuhan dan perkembangbiakan bakteri. Madu menghasilkan hidrogen peroksida yang bertindak sebagai antiseptik.

Penelitian yang dilakukan oleh Arif (2013) juga membuktikan madu dapat mempercepat kesembuhan luka bakar pada manusia, karena madu mempunyai efektifitas anti inflamasi, anti bakteri dan stimulan regenerasi jaringan sehingga menghasilkan penyembuhan luka yang baik. Madu 
terdapat flavonoid yang dapat menghambat mediator-mediator radang yaitu mengurangi efek siokin (Interleukin-1 dan Tumor Necrosis Factor (TNF)) yang dihasilkan oleh makrofag dan sitokin reseptor yang secara umum akibatnya tampak pada penekanan rasa nyeri, demam dan kerusakan jaringan.

Penelitian lain yang dilakukan oleh Wulandari (2017) juga sejalan dengan penelitian lainnya yang membuktikan bahwa madu lebih efektif terhadap penyembuhan luka. Hal ini dikarenakan madu dapat meningkatkan waktu kontraksi pada luka. Madu efektif sebagai terapi topikal karena kandungan nutrisi yang terdapat di dalam madu. Madu mengandung $40 \%$ glukosa, $40 \%$ fruktosa, 20\% air dan asam amino, vitamin biotin, asam nikotinin, asam folit, asam pentenoik, proksidin, tiamin, kalsium, zat besi, magnesium, fosfor, dan kalium. Madu juga mengandung zat antioksidan dan $\mathrm{H}_{2} \mathrm{O}_{2}$ (hidrogen peroksida) sebagai penetral radikal bebas yang bekerja mendenaturasi protein dan menghambat sintesis atau fungsi dari asam nukleat bakteri dengan adanya kerusakan pada dinding sel bakteri dan gangguan pada sintesis asam nukleat, maka pertumbuhan bakteri akan terhambat.

\section{KESIMPULAN}

Adapun simpulan khusus dari penelitian ini adalah sebagai berikut:

1. Usia terbanyak dalam penelitian yaitu pada kelompok usia 56-65 tahun. jumlah 7 responden $(19,4 \%)$. Berdasarkan jenis kelamin terbanyak yaitu perempuan dengan total 21 responden $(58,3 \%)$. Berdasarkan jenis cairan, didapatkan penggunaan cairan ringer laktat lebih banyak dengan jumlah total 35 responden $(97,2 \%)$.
Berdasarkan ukuran IV kateter, menunjukkan responden lebih banyak terpasang terapi intravena (infus) menggunakan ukuran IV kateter nomor 20 dengan total 27 responden (75 \%). Berdasarkan letak pemasangan terapi intravena, didapatkan hasil letak pemasangan terbanyak yaitu pada daerah permukaan dorsal tangan dengan jumlah 28 responden $(77,8 \%)$.

2. Pada penelitian terhadap kelompok kontrol dengan jumlah responden 18 orang, di dapatkan hasil ratarata (mean) kejadian flebitis adalah 0,94.

3. Pada penelitian terhadap kelompok intervensi dengan jumlah 18 responden yang diberikan intervensi pengolesan madu pada saat pemasangan terapi intravena, didapatkan hasil rata-rata (mean) kejadian flebitis adalah 0,33.

Pada penelitian ini dapat di disimpulkan bahwa terdapat pengaruh pemberian madu saat pemasangan terapi intravena terhadap pencegahan flebitis di Instalasi Gawat Darurat Rumah Sakit Universitas Tanjungpura Pontianak.

\section{UCAPAN TERIMA KASIH}

Dalam kesempatan ini saya akan menyampaikan terima kasih banyak kepada :

1. Kepada orang tua tercinta yang telah banyak berkorban tanpa lelah untuk memberikan support moral, moril dan material.

2. Ketua STIKes Yarsi Pontianak yang telah memfasilitasi saya selama penelitian

3. Kepada pembimbing pertama dan kedua saya yang telah banyak memberikan masukan dan saran sehingga saya bisa di titik ini.

4. Kepada teman-teman satu 
Angkatan yang luar biasa memberikan semangat dan support system selama penelitian.

5. Dan kepada responden yang telah bersedia untuk menjadi responden pada penelitian ini.

\section{REFERENSI}

Alexander,et al (2010). Infusion Nursing: An evidence Based Approach.

Arif, MZ (2013). Perbandingan Tingkat Kesembuhan Luka Bakar dengan Pemberian Madu dan Pemberian Gentamicin Topikal pada Tikus Putih. (http://www.jukeunila.com.diunduh pada tanggal 06 Oktober 2017).

Dharma, Kelama Kusuma (2011). Metodologi Penelitian Keperawatan Panduan Melaksanakan dan Menerapkan Hasil Penelitian. Jakarta : CV. Trans Info Media.

Fitriyanti, Sepvi (2015). Faktor yang Mempengaruhi Terjadinya Phlebitis di Rumah Sakit Bhayangkara TK.II.H.S.Samsoeri Mertojoso Surabaya.(http:// ejournal.unair.ac.id.diunduh pada tanggal 29 November 2017).

Gunawan,Nina Amelia (2017). Madu: Efektivitas untuk Perawatan Luka.(http://www. kalbed.com.diunduh pada tanggal 04 Oktober 2017).

Nasution, Lukmanul Hakim (2012). Infeksi Nosokomial (http://www. portalgaruda.com. diunduh pada tanggal 04 Oktober).

Ningsih, Neneng Fitria (2012).Hubungan Terapi Cairan Intravena Terhadap Kejadian Flebitis di IRNA Bedah RSUD Selasih Kabupaten Pelalawan.(http://www.journal.stkiptam .ac.id.diunuduh pada tanggal 04 Oktober).

Nursalam (2017). Metodologi Penelitian Ilmu Keperawatan:Pendekatan Praktis Ed.4.Jakarta: Salemba Medika.

Oktyaningrum, Rizka (2016) Hubungan Antara Kesesuaian Ukuran dan Letak
Pemasangan Intravena Kateter Terhadap Kejadian Flebitis Di RSUD Ungaran

(http://www.perpusnwu.web.id.diunduh pada tanggal 26 Nov 2017).

Ollivera, Anabela Salguelro,et al (2012). Incidence Of Phlebitis In Patients With Peripheral Intravenous Catheters :The Influence Of Some Risk Factor (http://www.galegroup.com.diunduh pada tanggal 04 Oktober 2017).

Phillips, Lynn D \& Lisa,A (2014). Manual Of I.V Theraupetic Evidance-Based Practice For Infusion Therapy. Philadelphia: F.A Davis Company.

Potter, Patricia A \& Perry, Anne Griffin (2006). Buku Ajar Fundamental Keperawatan. Konsep, Proses, \& Praktik.Ed.4. Jakarta : EGC.

Rizky, Wahyu (2016). Analisa Faktor Yang Berhubungan dengan Kejadian Phlebitis pada Pasien yang Terpasang Kateter Intravena di Ruang Bedah Rumah Sakit Ar. Bunda Prabumulih. (http://www.ejournal.almaata.ac.id.

Diunduh pada tanggal 5 November 2017).

Soraya, Rissa (2014).Perbedaan Efektivitas Antara Balutan Transparan dan Balutan Kasa Terhadap Kejadian Phlebitis di RSUD Kota Salatiga.(http://www.ejournal.unair.ac.id.diunduh pada tanggal 28 September 2017).

Wulandari, Diah (2017). Perbedaan Penyembuhan Luka Perineum Pada Ibu PostPartum Dengan Madu VS Povidon Iodine di $R b$ Amanda Yogyakarta (http://journal.unsika.ac.id.diunduh pada tanggal 28 November 2017). 